\title{
Muslims and Diplomacy
}

\author{
Karim D. Crow*
}

Diplomacy is normally understood in the context of international relations or relations between states which communicate for purposes of cooperation, rivalry or strategic advantage, and regulating exchanges for mutual benefit. Historically, diplomatic relations between states were marked by competition and strategic exchanges (e.g. impressive gifts), promoting trade and commerce, as well as gathering intelligence. Diplomacy could also be a prelude and preparation for warfare, and/or for arbitration and negotiating terms of peace to end war. Diplomats, spies, and merchants often mingled their activities in searching for a comparative advantage against another ruling polity.

Until recently, interstate relations - whether competitive, cooperative or complementary - remained confined to a function of nation states, with diplomacy conceived as a defining characteristic of the state in the international system. The self-interest of the nation-state determined the parameters of 'security' - defined in the limiting terms of 'state security' as perceived by ruling elites and power brokers. However, a wider more inclusive idea of 'human security' is now gaining ground, exercising an impact on the policies of state elites. Notions of 'trans-national' security and 'non-traditional' security (covering natural disasters, regional economic upheavals, countering trans-national terror, etc.) are today accepted as legitimate areas of concern by many governments. Given this transformation in our understanding of security, should Muslims also begin thinking of exercising diplomacy in more flexible ways?

\section{The Emergence of a Regionalised Multi-Polar System}

Our globalised world in the early twenty-first century is witnessing the gradual emergence of a regionalised multi-polar system. The dominant US-American power is waning economically and militarily, while major regional powers are ascendant notably in East Asia, India, and possibly in the Middle East. ${ }^{1}$ Globalising trends have caused immigration rates to skyrocket for most developed and developing countries. People journey afar to find employment and settle down where they are constantly surrounded by a culture quite different from their home country. International students abroad have to choose whether they are willing to modify their cultural boundaries by adapting to the surrounding culture or whether to hold fast to their culture and religion by living in an exclusive pocket of their countrymen within the host country.

* Karim D. Crow is Principal Research Fellow at IAIS Malaysia. 
Increasingly, the norm for the majority of humanity is the cosmopolitan environment of large urban collectivities where peoples of differing cultures and religions mingle. However, the urban reality often magnifies basic inequalities and severely strains the feasibility of sustainable development and social-economic progress. ${ }^{2}$

Global, communal, and individual security have now become inseparable and require that essential human needs be secured equitably: food, natural resources, energy, education, health, employment, as well as more intangible, yet equally crucial, ethical and spiritual needs. ${ }^{3}$ Complicating all these is the existential predicament of unintended evils which widespread application of science and technology is inflicting upon our planet and collective psyche ${ }^{4}$ - the blowback from modernity. Potential for rivalry and conflict is increasing, with violent bloodshed in several Muslim societies persisting unabated. Islamic norms of moderation, oneness, and dignity of humanity, just socio-economic order, reconciliation, and peaceful-security may appear remote or overly idealistic to pragmatic-minded officials and society leaders. How may Muslim societies and governments best position themselves within this shifting order? How may Islamic values and principles find meaningful application within the current system of international politics and state relations? $?^{5}$

Should the responsibility and direction for an Islamic-inspired diplomacy be left in the hands of the state alone? Or can Muslims conceive of an expanded engagement with the pressing issues of our day, by engaging in forms of citizen diplomacy which may potentially enliven the values and ideals preserved in Islam's legal, ethical and spiritual legacy? We now witness the emergence of popular social movements in the Arab world reaching for a more open, accountable and more transparent society - sometimes met by brutal oppression and state-engineered violence. Popular will, stoked by the energy and imagination of the youthful generation, reflects the transformation in thinking and expectations of a better educated urban population, with middle-class economic aspirations using free communication, who envision alternative futures. Ordinary citizens have created a wide social network of persons willing to actively participate in peaceful engagement for social transformation. However, will these people's movements succeed in embodying genuine Islamic ideals in realistic ways?

Several decades ago certain European and US-American thinkers and officials advanced new ideas on how to expand diplomacy. Informal or 'Track II' diplomacy is one specific activity where private citizens like scholars, retired civil and military officials, public figures, and social activists, engage in dialogue with the aim of neutralising conflict and arbitrating peace. Governments sometimes fund such informal exchanges or these efforts may have no connection with governments or might even act in defiance of governments. This mode of citizen diplomacy engages with officials, policy makers, scholars and civic leaders in order to build confidence and minimise the likelihood of violence in specific situations. It treats well-informed 
qualified individuals as valid diplomatic actors who could succeed where the state does not. These individuals must have the ability to communicate successfully with peoples of other cultures by possessing cross-cultural competence along with required regional and language competence.

\section{Toward 'Cultural Diplomacy’}

More promising in conception and practice may be 'cultural diplomacy'. This involves new non-governmental and non-professional actors engaging in diplomatic activities by means of exchanging ideas, information, value systems, traditions, faith-beliefs and related aspects of culture. In the framework of globalisation, human culture and religion play a major role in defining identity and conditioning relations between peoples. Cultural diplomacy rests on informed reciprocity and mutual recognition of another's distinctive cultural dynamics. Mutual understanding requires the study of foreign cultural dynamics in order to gain an appreciation of the traditions, history, language and worldview of the engaging party. Cultural relations create a special dynamic for meaningful dialogue - not necessarily for full agreement or approval, but for collaborative recognition and understanding built by consensus and shared interests. Cultural diplomacy tends to promote reciprocal acknowledgement of equal rights on equal terms.

'Cultural diplomacy' is essential for fostering and sustaining unions between nations as regional blocs (EU, Arab League, ASEAN), and is very beneficial for reaching agreements in trade, investment, immigration or inter-state security. Private and public institutions and corporations have long understood the utility of this mode of informed dialogue for sustaining mutual activities, and the same is true of NGOs and humanitarian agencies. When wisely practiced by governments or by society groups and civic leaders, cultural diplomacy may greatly benefit lives of ordinary people. This was the case with the abolitionist campaigns in the United Kingdom to ban slavery leading to the 1833 Slavery Abolition Act. The recognised importance of cultural diplomacy and pragmatic benefits of cultural exchanges has led to its institutionalisation by several governments.

In other words, 'cultural diplomacy' is an effective application of soft power, which means that persuasion through appealing to cultural ideals, ethical values and ruling ideas is more effective and beneficial than conquest or coercion by military power (e.g. the predator diplomacy practiced by the United States). Hard power is the ability to coerce, and soft power is the means to attract and persuade. It is true, historically, a hard power approach was the favoured policy by governments in conducting international and regional relations. For millennia classic diplomacy was conceived as projecting the security interests of the ruling polity, meaning the use of violence as the basis and ultimate sanction of power politics. However, our 
globalised world requires exchanges and cooperation on a higher level. This is why intercultural competence and training for understanding other religions and worldviews has now become reciprocally necessary - both for non-Muslims to appreciate Islam, and for Muslims to appreciate the cultures and peoples of other traditions with which they interact and coexist.

\section{Conclusions and Recommendations}

If we are to take 'human security' seriously in our global context, and successfully mitigate the negative effects of the 'state'-centred security concept, then contributions of Earth's leading civilisations will have to be integrated into our diplomatic thinking and practice. ${ }^{6}$ Muslims in particular retain valuable resources for accomplishing this transformation towards understanding security in human-centred terms. The Qur'ān is an extended exercise in persuasion providing important lessons to absorb. The Prophet Muhammad's mission clearly displayed a judicious combination of hard and soft power, and forms a worthy model that remains relevant today. Central Islamic principles and values - tafähum (reciprocal understanding), ta 'āwun (mutual assistance), ta'āruf mutual-recognition, and tasābuq (wholesome competition) - confirm the primacy of peaceable persuasion and harmonious reciprocity in exchanging ideas, goods, and persons for common benefit.

Muslims may be more imaginative in searching for principles and requirements providing direction for fulfilling pressing human needs:

- We need to comprehend how peace and security are embraced among the maquassid or 'higher objectives' of the sharì 'ah. We should remember that a selfless Islamic ethic of Humanitarian Intervention exists. ${ }^{7}$ Muslims tend to privilege juristic discourse and those concepts drawn from shari ${ }^{-} a h$ tradition, while ignoring major theological, philosophic and spiritual teachings.

- There exist untapped riches in corners of Islamic thought and experience commonly overlooked. Thus, the philosopher Abū Nașr al-Fārābī (d. 950/51) was the first major thinker to pay serious attention to conditions for a 'world state' and explore the components of a 'virtuous polity' (al-madinat al-fädilah) for implementing world peace. ${ }^{8}$

Might it be that potentialities rarely realised previously under historical Muslim polities or within legal schools could be reimagined and embodied as authentic Islamic possibilities in our emerging global order? Do Muslim thinkers and leaders possess the creative imagination needed to accomplish such a transformation? 


\section{Notes}

1. Samir Amin, Beyond US Hegemony? Assessing the Prospects for a Multipolar World, transl. Patrick Camiller (London and New York: Zed Books, 2006).

2. See the studies in Amiya Kumar Bagchi (ed.) with Gary A. Dymski, Capture and Exclude: Developing Economies and the Poor in Global Finance (New Delhi: Tulika, 2007).

3. Consult the magisterial overview by Amartya K. Sen, The Idea of Justice (London: Allen Lane, 2009).

4. Professor Hans Poser of Berlin terms evil consequences of today's secularised technology as 'technodicy', asking how the evil caused by technology is possible in light of the posited rationality of the human creator. In technodicy the human judges his own unanticipated works of evil (e.g. environmental pollution) - in parallel with the classical notion of theodicy where God does not intend evil yet must account for its existence in His creation. See H. Poser's paper read at World Philosophy Day Conference, November 2010, Tehran (forthcoming).

5. For increasing awareness of the impact of religion upon global politics, see Scott M. Thomas, The Global Resurgence of Religion and the Transformation of International Relations: The Struggle for the Soul of the Twenty-First Century (New York and Houndmills, Basingstoke [UK]: Palgrave Macmillan, 2005).

6. Consult the contributions in Douglas Johnston(ed.), Faith-Based Diplomacy: Trumping Realpolitik (Oxford: Oxford University Press, 2003).

7. Sohail H. Hashmi, "Is There an Islamic Ethic of Humanitarian Intervention?" Ethics and International Affairs 7 (1993), 55-73.

8. Richard Walzer (ed., transl.), Al-Farabi on the Perfect State (Oxford: Oxford University Press, 1985). Further discussion and analysis by M. Galston, Politics and Excellence: The Political Philosophy of Alfarabi (Princeton: Princeton University Press, 1990). 